\title{
Princely Patronage and Patriot Cause: Corruption and Public Value Dynamics in the Dutch Republic (1770s-1780s)
}

\section{Toon Kerkhoff}

To cite this article: Toon Kerkhoff (2016) Princely Patronage and Patriot Cause: Corruption and Public Value Dynamics in the Dutch Republic (1770s-1780s), Public Integrity, 18:1, 25-41

To link to this article: http://dx.doi.org/10.1080/10999922.2015.1093403

曲 Published online: 09 Dec 2015.

Submit your article to this journal $₫$

Q View related articles ¿

View Crossmark data ־ 


\title{
Princely Patronage and Patriot Cause: Corruption and Public Value Dynamics in the Dutch Republic (1770s-1780s)
}

\author{
Toon Kerkhoff \\ Leiden University
}

\begin{abstract}
While the usefulness of historical insight is often implicitly recognized in public values studies, it is rarely expressed in actual historical research. This article argues that historical analysis is well equipped to investigate public values and their dynamics (i.e., change and continuity over time). To illustrate this argument, the article presents a corruption scandal involving the regent Hugo Repelaer in the Dutch Republic of the 1770s and 1780s. The article shows how patronage and other forms of political behavior were contested on the basis of new and/or reemphasized public values and political principles, such as popular sovereignty and representation. It also shows the emergence of value monism in the Dutch context. An explicit link between the events of the case and theoretical perspectives on public value dynamics serves, furthermore, to increase the understanding of the latter and to elucidate present discussions. The article contends that a historical approach to public values can and should inform present-day attitudes to corruption and integrity, and offers promising avenues for future historical research on public values on a European scale.
\end{abstract}

Keywords: public value dynamics, corruption, dutch republic, political patronage, public integrity

\section{A HISTORICAL PERSPECTIVE ON PUBLIC VALUES}

In the disciplines of public administration and political science, scholars have long been interested in the (changing) normative foundations of social-political interaction. Much work has been devoted to understanding such crucial notions as the good life, public integrity, corruption, and the public and private interest. Often this entails a specific look at public values and what is called public value dynamics (cf. Van der Wal, Nabatchi, \& De Graaf, 2013).

Public values, to follow Bozeman's definition, are "those providing normative consensus about (a) the rights, benefits, and prerogatives to which citizens should (and should not) be entitled; (b) the obligations of citizens to society, the state, and one another; and (c) the principles on which governments and policies should be based" (Bozeman, 2007, p. 17). Moreover, as Oyserman (2001) further observes, public values are "priorities, internal compasses or springboards for action-moral imperatives" (pp. 16148, 16150). They are "implicit or explicit guidelines for action, general scripts framing what is sought after and what is to be avoided ... social agreements about what is right, good to be cherished" (p. 16151). Because public values are elements of

Correspondence should be sent to Toon Kerkhoff, Institute of Public Administration, Leiden University, Schouwburgstraat 2, 2501 EE, The Hague, the Netherlands. E-mail: a.d.n.kerkhoff@cdh.leidenuniv.nl 
changing social systems, they are constantly subject to reinterpretation (cf. Rutgers, 2008). Change and continuity in the meaning of public values, together with the emergence or decline of specific values over time, constitute public value dynamics (cf. Jørgensen \& Vrangbæk, 2011).

The current focus on public value dynamics seems, in large part, to be driven by an interest in the ethics of public-private arrangements (Jørgensen, 2009; Van Gestel, Koppenjan, Van de Schrijver, Van de Ven, \& Veeneman, 2008) and (new) public management (cf. Bozeman, 2007; Frederickson, 1999; Kolthoff, 2007; Maesschalck, 2004). As a result, the bulk of work in this area is predominantly centered on the contemporary situation, and often ignores the historical perspective (Jørgensen \& Vrangbæk, 2011, p. 486). This article contends, on the contrary, that historical inquiry is actually especially well equipped to investigate public values dynamics, and can aid present discussions on public integrity and corruption (cf. Kerkhoff \& Wagenaar, 2015). History is of use in understanding these dynamics because of its emphasis on time, its long-term perspective, and its attention to the intricate, incremental, contingent, and long-term workings of institutional contexts (cf. Pierson, 2003, p. 187; Pierson \& Skocpol, 2002, pp. 696-697; Raadschelders, 1994; Thelen, 2002). Calls for historical work on the topic, to be fair, can be heard earlier and elsewhere-for instance, in the "public values research agenda" of Jørgensen and Bozeman (2007, p. 355). At the same time, actual historical research of public values and their dynamics is still rare (for notable exceptions, see Jørgensen \& Rutgers, 2014; Jørgensen, Vrangbæk, \& Sørensen, 2009).

\section{A CASE OF EARLY MODERN DUTCH CORRUPTION}

To show the use of historical inquiry to better understand public values and-by extensionpublic integrity, this article offers a historical case pertaining to a corruption scandal. The scandal revolved around the behavior of the local magistrate Hugo Repelaer, in the 1770s and 1780s, in the town of Dordrecht in the province of Holland. The case serves the purposes of this article for two main reasons. First, it provides a view on (moral) reform of public administration resulting from widespread patronage and other "corruption" in the Dutch Republic at the time. The term "corruption" is used broadly in this article to denote lack of integrity (for elaborate historical and conceptual analyses, see Buchan \& Hill, 2014; Friedrich, 1989; Heidenheimer \& Johnston, 2001). It is defined here as "the abuse, according to the legal or social standards constituting a society's system of public order, of a public role or resource for private benefit" (Johnston, 1996, p. 333). Because discussions regarding corruption are essentially about values, and right or wrong, an account of this corruption scandal is a useful way to show which public values were at play.

Second, the events of the case take place in a period of major institutional and moral transformation, in which old "patrimonial" ways were slowly but steadily replaced by "rational-legal" principles. Critique of a government that was mostly comprised of the personal property of its officials went hand-in-hand with a change in values as well as steps to create a government subject to bureaucratic rules and increased public scrutiny. The case, therefore, revolves around conflict, scandal, and public debate regarding Repelaer's behavior. This is highly useful, as it makes explicit and visible public values and ethical ideas that are usually implicit and hidden (cf. Kerkhoff, 2013b, pp. 47-49). The use of scandal (in a methodological sense) offers a unique opportunity to reconstruct the opinions, allegations, and arguments of the various actors involved, from which it is possible to distill and interpret public values. In turn, 
this enables a better understanding of how these values acquired meaning in a specific time and place (cf. Johnston, 1996, 2005, p. 72). Historical analysis of struggle and arguments in a debate is able to focus on discussion and disagreement. It can, therefore, assess public value conflict to help us understand value dynamics (cf. Jørgensen \& Vrangbæk, 2011, p. 487; Tilly, 2008).

The analysis of the case study is based on the interpretation of primary archival material of 18th-century Dutch pamphlets, a popular media outlet used by anonymous "observers," public officials and moral authorities of the day who provided their opinions on various public matters (cf. Broersma, 2005; Pollmann \& Spicer, 2007). While pamphleteers were hardly ever neutral in debates, their words should not immediately be taken as fact. However, their writings do provide a rare and therefore invaluable view on the values and ideas uttered in the public debates of the time. The information from the pamphlets is supplemented by secondary literature on Dutch history of ideas and administration to better understand the events of the case in their proper historical context, as it was understood by different actors in late 18th-century Dutch society.

\section{PRINCELY PATRONAGE AND PATRIOT CAUSE: THE CORRUPTION OF HUGO REPELAER}

\section{System of Recommendations and Moves Toward "Political Purity"}

In the midst of the trans-Atlantic revolutionary sentiment of the 1770s, critiques of age-old administrative practices emerged in the Dutch Republic (cf. Israel, 1998; Palmer, 1954; Schama, 1977). The period was important, as a number of reform-minded and politically inspired authors used the blossoming press to explicitly aim at structural and moral improvement of Dutch public administration (Kerkhoff, 2014). A powerful current of revolutionary zeal and a desire for administrative moral reform led to a near-constant moral reassessment of the position and functioning of "proper" public officials (cf. Israel, 1998, pp. 1120-1121; Leeb, 1973; Schama, 1977, pp. 64-79).

Chief among the new (or reemphasized) public values were political participation, civic freedom, and popular sovereignty and representation for ever larger and more diverse groups of people outside the as yet closed oligarchy of city regents. Public values such as loyalty, integrity, justice, and accountability acquired new meaning in Patriot ideology, as they were explicitly connected to widening notions of "people," "community," and "common interest." Various Dutch political reformers (cf. Kerkhoff, 2014), such as Joan Dirk van der Capellen (1741-1784), Johan Hendrik Swildens (1745-1809), Willem Ockerse (1760-1826), and Isaac Gogel (1765-1821), went against the tide and demanded that public officials be humble, neutral, and fair (i.e., bureaucratic) custodians of the people's interests rather than "despotic" usurpers (cf. Zwitser, 1987, pp. 21-22). The Patriot political program-tellingly entitled The Constitutional Restoration of the Dutch State (Swildens, Van der Capellen, \& Van der Capellen van de Marsch, 1785) was a powerful moral plea, a "catechism of political purity" (Van Sas, 2005, p. 213).

Patriot values converged with the struggle against the prevailing system of acquiring public office by means of patronage and nepotism, especially in the shape of so-called "stadtholderly recommendations." In short, this meant that the incumbent Dutch stadtholder-his office a remnant of late medieval Burgundian-Habsburg patronage in the Low Countries and a powerful political figure in his own right since the Dutch Revolt (cf. Israel, 1998, pp. 300-306)—often 
had the right to choose people for public office in many local town councils. He would select candidates from a short-list handed to him by the leader of the dominant faction in the town council. As a result, the stadtholder chose people based on the advice of the local representative, who made sure that like-minded regents (those in favor of the regent's faction as well as a strong stadtholder) would get the most desirable positions. In this way, both representative and stadtholder could protect their local interests.

In this system, the local representatives-called "confidants" of the stadtholder-became patrons themselves and used this power to improve their own situation. Confidants, for instance, arranged, sold, or gave away public offices to friends and family for personal gain. In doing so, they often ignored the long-standing collegial practice of office rotation based on the seniority of town council membership. The average town council in Holland consisted of, at most, 40 regents, and membership was for life. However, access to lucrative and important public positions, such as magistrate (judge, mayor, etc.) or city delegate in a provincial or union college, was temporary and usually based on how long someone had been waiting his (never hers) turn. The confidants turned this system upside down. Those critical of stadtholder or confidant politics were purged or given bad (i.e., less influential and/or lucrative) offices (Gabriëls, 1989, pp. 145-149, 152-153; Israel, 1998, pp. 1082-1084). Patronage and nepotism were the tools the members of the regent oligarchy used to maintain "harmony" in their closed circle and to serve private or family interests.

From the 1770s, Patriot protests against these practices could be heard ever more clearly (Kerkhoff, 2014). The Patriots wanted "their" public officials to be loyal and accountable to the people (Zwitser, 1987, pp. 3-5), and to a wider political community (cf. Groenveld \& Wagenaar, 2011; Price, 1994). As discussed in the above-cited works, this view was explicitly connected to new or reemphasized public values. A good administrator was to uphold his oath and duty to the nation and its people, and was to subordinate personal interests to those of the "common land" (cf. Israel, 1998, p. 1099; Zwitser, 1987, pp. 52-54). Subsequently, from Patriot times onward, public officials were often accused of corruption in terms of the supposed lack of a polity-wide impact of their actions. Likewise, moral decay was usually linked-in a quite classical sense-to corruption or decay of the body politic as a whole, including wider areas of society, such as politics, the economy, and culture (cf. Buchan \& Hill, 2014; Stapelbroek, 2010).

\section{Corruption of Hugo Repelaer}

Dordrecht was one of the towns where the stadtholder could, in fact, appoint people to public office via his confidant. In Dordrecht this was Hugo Repelaer (1730-1804), member of an old Dordrecht aristocratic regent family (cf. Palmen, 1998, p. 212). Repelaer had become a member of the Dordrecht town council in 1756 and subsequently held various highly lucrative public offices (Molhuysen, Blok, Knappert, \& Kossmann, 2008, part 4: 1140). In 1770/1771 he became the Dordrecht confidant of Stadtholder William V (1766-1795) and "power broker" between Dordrecht and the court in The Hague. At least according to popular opinion, he (ab)used his position well. In 1770, as described by one pamphleteer (Van Putten, 1782, p. 9), Repelaer had apparently appointed a friend as receiver of the common means (a lucrative tax office). In 1772 he also had Paulus van der Heim appointed by the Estates-General as second secretary of the Admiralty of Rotterdam (Repelaer, 1772). Paulus was the son of Rotterdam mayor Jacob 
van der Heim, who was likewise involved in "shady" dealings and became a focus of Patriot agitation (Kerkhoff, 2013b, pp. 162-171). Since Repelaer and Van der Heim were related (their wives were cousins), this was considered nepotism (cf. Gabriëls, 1989, part VI: 522, footnote 534).

Similar accusations were made when Repelaer asked the Estates-General to appoint his son Ocker (1759-1832) as assistant receiver of the Convooien and Licenten in 1779 (Repelaer, 1779). This entailed the lucrative right to levy money from shipping companies, on behalf of the navy, for the protection of their merchant ships and rights imposed for the transport of goods to enemy territories. Repelaer's disregard for seniority, or "proper" office rotation procedures, made enemies within and outside the town council. Criticism of his behavior was also an important catalyst for the Patriot push to eventually abolish the system of recommendations in August 1782 (Gabriëls, 1989, p. 237). Repelaer and the scandal surrounding his behavior thus coincided with a pivotal moment in the Patriot Revolt of 1780-1787 (Israel, 1998, pp. 1098-1112).

Repelaer's conduct was debated in various pamphlets. One example hailed the August 1782 decision and lashed out against the former system as well as Repelaer when it stated that now the "courageous [Patriot] regents valued freedom over treasure, honor over life." They withstood tyranny and were praised for their virtue, as befitting the "gray-haired old man"- the former grand pensionary Johan van Oldenbarnevelt, a symbol of proper regent administration to everyone who hated the stadtholder and his cronies. Now, the pamphlet continued:

bribery has been warded off, the chair of the mayors no longer occupied by flatterers. No slave bowing for favor and oppression will any longer approach the honorable council chamber. (Missive van een Haagsch Patriot, 1782, pp. 12-13; cf. Tweetal lofdichten op de pattriottische resolutie, 1782, p. 3)

The pamphlet ended with an appeal to quash all the other "Repelaers" in the Republic, with Repelaer turned into an example to push for moral administrative reform of the Republic as a whole. Interestingly, this hints at the novel suggestion of the Patriots to further a national instead of a provincial movement, and is a telltale sign that they had wider and more inclusive ideas of the common good and public interest than hitherto espoused (cf. Price, 1994).

\section{Fundamental Debates and Public Values}

Patriot attacks on recommendations in general, and Repelaer in particular, boiled down to the fundamental question of exactly what constituted a good or bad regent (cf. De herstelde vrijheid, 1782, pp. 2-4). This question was central to one important pamphlet on the case, written in 1782, after the ending of the recommendations, by Johan Bareuth, a Dordrecht preacher, stadtholder supporter, and moral authority of the day. Bareuth stated that the regents of Dordrecht who had ousted the stadtholder and his confidant had themselves only acted out of self-interest. In a rhetorical question, he wanted to know what this meant for their morals and principles. To him, the regents' motives for deposing the stadtholder and Repelaer had not been "pure." Significantly, he pointed to a difference between acting in the public interest and in one's own personal interest, and concluded that the remaining council regents after 1782 had done the latter. Bareuth called them hypocrites who had very little to do with "true," or selfless, Patriotism (Bareuth, 1783, pp. 3-4). 
To Bareuth, the Dordrecht town council was an oligarchy under Repelaer, who led it before 1782, and also under the Patriot regents after 1782. In both cases it failed to protect the privileges of citizens and stadtholder as a result of the regents' self-interest. They failed to "live up to the great lesson of conscience: Do not do unto others what you do not want others to do unto you" (Bareuth, 1783, p. 3). In another rhetorical question, Bareuth asked whether it had "been the consideration of duty to uphold the privileges of their cities or the self-interest, advantage and the urge one has to clip the wings of the stadtholder?" (Bareuth, 1783, p. 4). The town council was then urged to return power to the citizens, because only then "shall they deserve the praise that true Patriots deserve" (Bareuth, 1783, p. 23).

Many more such pamphlets provide the impression of a debate on the core values of representation, self-interest, and public interest. One of them criticized the town council because it had not halted the

arbitrary recommendations in giving offices [since] Repelaer had done nothing else than betray the trust invested in him by the stadtholder only to get for himself and his family in the most illegal way the favors of government, proven by the number of functions he has gotten out of turn and only because of the favor of the stadtholder. (Missive van den heer L. V. J. aan den heer P. G. Z., 1782, pp. 3-4)

Repelaer was then berated for his ploys to get an office for his son Ocker (see earlier comment), and his apparent (failed) scheme to get his second son, Johan Repelaer (17601835), a lucrative office as well. "Father Repelaer" had been so keen on obtaining offices for himself and his family that

as soon as anyone gets sick he takes this position for himself or his children, which is easy for him, since the stadtholder has put his faith in him and believes no one loves him more or does more for him in the city of Dordrecht. (Missive van den heer L. V. J. aan den heer P. G. Z., 1782, p. 4)

Other interesting public value statements are found in this pamphlet. One criticism holds that Repelaer acted selfishly and disregarded the nation's interests because of disregard for proper (proto-bureaucratic) procedures. His way of distributing offices was unbearable because it was

solely dependent on arbitrary goodness, to get douceurs [gifts] instead of being dependent on the order of government [rotation based on seniority]. His authority is accompanied by an unbearable haughtiness and contempt for his fellow regents, claiming to be a man without whom no office in Dordrecht can be acquired. (Missive van den heer L. V. J. aan den heer P. G. Z., 1782, pp. 5-6)

The pamphlet then unfolds a vision of the right kind of government for Dordrecht, which was to consist of:

delegates who feel subordinate to the responsibility of their principals, who have freedom-loving feelings and display enough resolve to govern their city in accordance with the wishes of their able pensionary. (Missive van den heer L. V. J. aan den heer P. G. Z., 1782, p. 14)

It continued by saying that end of personal recommendations and free deliberations had finally been safeguarded because in the former system

even the most able, powerful, and selfless regent will find it hard to serve his country when he is robbed of offices that should have been his by cowardly flatterers and courtiers (Missive van den heer L. V. J. aan den heer P. G. Z., 1782, p. 15) 
To the post-1782 regents in the town council, the values of delegation (of authority) and free deliberation seem to have meant being free from the influence of the stadtholder and his confidant. Unlike the more "hard-line" Patriots, such as Van der Capellen or Van Putten (see below), they seem to have had little consideration for popular representation or accountability to the people. One pamphlet—anonymous, but likely written by a formerly excluded regent-argues that recommendations and patronage had caused political power to move away from its original base, the cities and regents. As it counters attempts at centralization by stadtholder and confidants, it stated:

when the central nerve [local city administration] is struck by disease, calamity must follow through all branches of government, and its pernicious influence will be felt everywhere. (Intressant vertoog over het bedanken, 1782, p. 4)

Here the corruption or degeneration of the entire political system is said to have been caused by recommendations and confidants, because, the pamphlet continues:

those regents who obtained offices through the stadtholder will not counter him. They will use their opportunities to indulge in their main motives of glory, lust to rule, and self-interest. (Intressant vertoog over het bedanken, 1782, p. 5)

Another outspoken pamphlet was written by one Gijsbert van Putten. The name was most likely a pseudonym dedicated to two Patriot heroes who both originated from Dordrecht. One was Cornelis de Gijselaar (1751-1815) (Gijsbert?), who served as pensionary of Dordrecht between 1778 and 1787 and was one of the main Patriot leaders in the 1780s alongside Van der Capellen and others (Molhuysen et al., 2008, part 10: 309-310). The other was the famous Cornelis de Witt (1623-1672), brother of Grand Pensionary Johan de Wit and fierce opponent of the stadtholder, whose manor in South-Holland was in the town of Putten. The pamphleteer targeted Repelaer and princely patronage, and called upon the citizens to get rid of the stadtholder's favorites-by means of military force if necessary-to ensure the common good. They were to be replaced by men "not blinded by the glitter of gold, in whose soul no ignominy can be found" (Van Putten, 1782, p. 2).

Several of Repelaer's bad characteristics were then emphasized by Van Putten, such as a lack of caution-mostly in the sense of not adhering to the codes of collegial office rotation. In a clear and typical attempt to discredit him as corrupt, Repelaer was accused of adultery and having loose sexual morals (Van Putten, 1782, p. 4). Van Putten furthermore described Repelaer as "known throughout the city as a true courtier ... someone willing to do anything to get what he wants, thereby forsaking oath, honor, duty and conscience." He tells of how Repelaer used all the "scheming, intriguing, or cunning ways that he knew of to get what he wanted" (Van Putten, 1782, pp. 4-5). Repelaer was

always worshipping the rising sun... [and] used all his influence to protect and serve the interests of the stadtholder, for which the latter fattened up him and his friends, as long as there was no villainy they would not commit. (Van Putten, 1782, pp. 7-8)

Hugo Repelaer's political career ended (see below) with the 1782 decision of the town council - forced by Patriot ideas and civil militias - to end the system of personal recommendations. He was not actually removed from the council but chose not to submit to the new regulations and therefore stepped down of his own accord. Although he was bound by an oath 
of office and other formal instructions, he would not be judged by any legal standard-not even the post-1782 Patriot town council regulations (cf. Bedenkingen over het aanstellen van regenten, 1787; Gabriëls, 1989, pp. 269ff). He was never charged with any criminal offense or summoned to appear in court. This was, perhaps, because the case would have been difficult for the legal system to handle. Repelaer's actions (not unlike many acts of "corruption" today) could not easily be branded as illegal. The system of recommendations had been a mix of formal but mostly informal and unwritten rules, procedures, and practices. In addition, Repelaer's social standing must have prevented prosecution. In 1782, Repelaer was still a powerful figure with money, connections, and offices. Fears for revenge in case of the possible return of his patron, the stadtholder, must also have kept critical Dordrecht regents from actively seeking prosecution. This can, in hindsight, be considered a wise decision. Repelaer was reinstated as confidant in Dordrecht after 1787, when the stadtholder returned after the ultimate failure of the Patriot revolt.

\section{PUBLIC VALUES AND THE DYNAMICS OF INTEGRITY}

In the preceding sections we have discussed the case of Repelaer in detail. In what follows, aspects of the case are linked to three theoretical approaches from the history of public administration and the public values literature commonly used to assess public value dynamics. These are (1) the role of bureaucratization, state-formation, democratization, and politicization; (2) the idea of structural functionalism and a systems approach; and (3) the notion of conflicting values.

\section{Bureaucratization, State-Formation, Democratization, and Politicization}

Historical work on corruption and changing morality has traditionally leaned heavily upon the idea that processes of bureaucratization, state-formation, democratization, and politicization are important catalysts for moral change. More specifically, a Weberian ideal-typical approach that centers on bureaucratization (as compared to the ideal-type of patrimonial administration, see Adams, 2005; Hoenderboom, 2013, pp. 42-47, 163-175) is often taken as a promising way to explain public value dynamics. From a "Weberian" point of view, corruption occurs as a result of deficient rationalization. It is a phase on the route from patrimonial authority, based on kinship, heritage, or wealth, to rational legal authority, based on rule of law, fixed procedures, neutrality, and other characteristics of Weber's ideal type (Kerkhoff, 2011; Raadschelders \& Rutgers, 1996, p. 97; see also Rubinstein, 1983).

Bureaucratization is closely related to the processes of state-formation, democratization, and politicization that, presumably, also affected changing public values and political ideas and vocabulary, especially during the boom of the emerging political press during the later years of the Western European Enlightenment (cf. Bayly, 2004; Koselleck, 1972; Richter, 1995, pp. 19-20). The rise of a political press had a major impact on changing public values, because it gave a voice to newly politicized groups of people who were able to claim a bigger share of the political pie (see Baker, 1987; Bayly, 2004; Broersma, 2005). This enabled crucial political and popular discussion about the moral grounding of politics and administration. 
The case of Repelaer provides evidence of when, why, and how these connected processes of bureaucratization, state-formation, democratization, and politicization influenced public value dynamics. Informal practices of recommendations and patronage were to be replaced by formal and more bureaucratized procedures, in which more people would have an honest shot at public office. The case provides evidence of a bureaucratic, rather than a patrimonial, reinterpretation of the public values of loyalty, representation, accountability, responsibility, participation, and public consultation. This reinterpretation was also based on more inclusive and wider notions of a Dutch "national" political community. Changing ideas on the state and the role of government were part-and-parcel of the changes in public morality. This becomes apparent in the Patriots' desire for public officials to serve wider communal rather than narrow particular interests. The case of Repelaer shows how long-standing assumptions about "proper" administration, of nepotism and patronage, changed in the context of increased politicization and calls for democratization. The case shows discussion between opposing parties in a highly dynamic social atmosphere in which core public values gained radically new meanings.

\section{Structural Functionalism; or, The Loss of a Need to Be Corrupt}

Another related key idea that is often used to explain public value dynamics is structural functionalism. Here society is seen as a collection of coherent systems in which all phenomena have specific functions. Scholars of corruption who adopt such an approach (cf. De Zwart, 2010; Riggs, 1964) ask whether different values and value systems can coexist at the same time, and what happens when there is a collision between values from different "systems." A structural-functionalist approach to public value dynamics also purports to understand when, why, and how the appropriateness and/or acceptance of certain forms of public official behavior vary depending on institutional structure. This approach stresses that what is today considered corruption was not always perceived as such, because of the specific structure of early modern society. It may have, instead, been highly appropriate, because of its function in political life (cf. Blockmans, 1988; Waquet \& McCall, 1991, p. 62).

This approach to public value dynamics is closely connected to bureaucratization. One could argue, for instance, that certain forms of public behavior became obsolete because their place was taken over by bureaucratic structures and new political-administrative arrangements, such as salaries, standard procedures for promotion, and strict adherence to formal hierarchical structures. As such, patronage was at one time justified because it provided protection and influence for groups in society that possessed material wealth but lacked political influence (Waquet \& McCall, 1991, p. 62). It actually facilitated action between the central and local levels (Blockmans, 1988; Huiskamp, 1995), and initiated and stimulated political processes that might otherwise never have been possible (Welskopp, 2010, p. 222).

The case of Repelaer shows how patronage was no longer automatically regarded as good, necessary, or functional. A structural-functionalist approach to the case shows how changes in the bureaucratic structure and functioning of the Dutch state and its cities had major consequences for what was deemed acceptable public official behavior. Acts of patronage, bribery, nepotism, deriving personal gain from public office, scheming behind closed doors, and excluding capable people from public office were increasingly deemed inappropriate because of changes in the structure and functioning of the state. The latter simply decreased the need to 
resort to such practices, since viable alternatives were now presented. This can be seen in the Patriot program to end stadtholder patronage and confidant abuse of office in the restructuring of many city governments in 1782 . The aim was to end, or at least decrease, the need for patronage, as patrons were to lose any beneficial function their role once had. In a way, patronage, nepotism, and similar forms of what was now deemed "corrupt" behavior lost their raison d'être. The Patriot critique of the Repelaers of their world, and their attempt to reform the local town councils, which failed in 1787 , had been explicitly meant to decrease the need for informal ways of delegating and using political power and authority. Despite the fact that Repelaer was reinstated as a confidant in 1787 , the seeds of a major moral change for the future had been sown (Kerkhoff, 2013a, 2013b, 2014).

\section{Conflict, Discussion, and Public Value Dynamics: From Pluralism to Monism}

In the case of Repelaer, conflict between various actors and their ideas on what was proper can clearly be seen. A third and final theoretical perspective stresses the need to look at the opposition between public values and their carriers, arguing that the meaning of the former largely depends on the power of the latter (cf. Beck Jørgensen \& Vrangbæk, 2011, p. 487). Conflict over public values due to a changing balance of power can trigger organizational responses as well as lead to new or reinterpreted public values (pp. $490 \mathrm{ff}$.). Some sociological and historical work on conflicting values and systems departs from similar assumptions. Luhmann's theory of social systems (Luhmann, 1970), for instance, assumes that society is divided into separate selfreferential value systems. Changes in public values and value systems occur when discussion and debate emerge as these social systems (legal, scientific, economic, political) start to overlap or clash (Brans \& Rossbach, 1997, p. 425; Grüne \& Tölle, 2013; Hiller, 2010, pp. 64-82; Luhmann, 1980, p. 162). The social historian Hillard von Thiessen has likewise shown how conflicting and competing standards were characteristic of early modern administration, and how this was a potential catalyst for changing values (cf. Kerkhoff, Hoenderboom, Kroeze, \& Wagenaar, 2010; Von Thiessen, 2009, 2010).

Similar dynamics can also be seen in the case of Repelaer. His actions and the stadtholder's patronage were not criticized only by ideologically inspired Patriots. He was also attacked by more practical, if not self-serving, local regents who had been excluded from full participation in government. Patriot ideologues and sidelined regents were therefore all fighting against a system of patronage, but they did so for different reasons. The first turned against nepotism and patronage because such practices harmed the "public interest," including popular sovereignty, political participation, and protection of citizens against arbitrary rule. The second group was merely looking for ways to get rid of the stadtholder and his confidants, so that they could again return to town council politics of collegial harmony and office rotation based on seniority. Even though the ousted regents won in the short term, the essential point is that the Patriot ideology was victorious in the end. As discussed elsewhere, Patriot public values would ultimately be triumphant in the Dutch Batavian Revolution of 1795 (cf. Israel, 1998, pp. 1105-1106, 1120-1121) because the Patriots proved to be more long-lasting and more powerful "value carriers."

The core contrast between opposing groups, their different attitudes toward proper public official conduct, and the eventual "moral victory" of the Patriots provides evidence for the idea that the Dutch Republic of the 1770s and 1780s witnessed the emergence of ethical monism. In 
line with research on later periods (Kerkhoff et al., 2010), the time and case of Repelaer show the beginning of a transition from value pluralism to value monism. Although these concepts can be applied differently, value pluralism is defined here as the coexistence of multiple and sometimes conflicting public values in a system or collection of values, whereas value monism is defined as the adherence to a single set of relatively undisputed public values in a single system based on shared understanding.

Different parallel value systems of a bureaucratic and a patrimonial system continued to coexist for decades to come (Nützenadel, 2009, pp. 121-142; Von Thiessen, 2010; Wagenaar, 2011, pp. 1-2), and still exist today. After all, there will always be individuals who believe they can function within different value systems at the same time. However, the late 18th-century Dutch turn toward monism meant that it became increasingly less desirable to adhere to different systems at the same time, and to adhere to the patrimonial one in particular. While this, naturally, does not apply to all times and places (for subsequent different views, see Grüne \& Tölle, 2013; Kerkhoff, 2013a), Dutch casuistry, as can be seen in the example of Repelaer and in other work as well (Kerkhoff et al., 2010), does suggest such a crucial shift for the Dutch context. The tide of public and legal opinion in the Republic slowly but steadily turned against certain practices, starting in the 1770s, in favor of a single public value system consisting of bureaucratic rules and Enlightenment and post-French Revolution ideals. This signals a shift in early modern Dutch normative foundations of government as a result of conflict, clashing ideologies, and subsequent political and moral reform. The Patriot era, as the case of Repelaer shows, was characterized by conflicting value systems (held by opposing social groups), and continued attention from Patriot political reformers would eventually lead to a slow displacement of patrimonial administration as the only proper way to govern. The continuation of many Patriot values in present-day Dutch public administration proves as much.

\section{CONCLUSION, LESSONS, AND A LOOK AHEAD}

While a single historical case study is insufficient to make sweeping generalizations, it can increase our understanding of social phenomena (Mahoney \& Rüschemeyer, 2003, pp. 6-9; Thelen, 2002, p. 94). In this way, the case of Repelaer does not provide a general theory or a fixed set of causal factors that always lead to changes in public values. Instead, it offers in-depth and nuanced insight into meaningful causal relations between a changing institutional environment, on the one hand, and social change, on the other (Hewitson, 2014; Raadschelders, 2000, p. 40). The case offers information on a changing administrative and social system in the late 18thcentury Dutch Republic. The debate surrounding Repelaer has shown the emergence of new values, new attitudes regarding acceptable behavior, and new parameters for "proper" public official conduct. Use of the theoretical lenses of bureaucratization, state-formation, democratization and politicization, structural functionalism, and conflicting public values has thus served to further the general understanding of public value dynamics.

The examination of the case offers more ways to elucidate present debate and research on public integrity. One obvious lesson is that, despite some similar situations, the present differs notably from the past in its views on correct public behavior. In the case of the Netherlands, for instance, nepotism and political patronage were, by and large, considered acceptable around 1750, but are no longer tolerated today (although they still occur, of course). However, a historical perspective 
emphasizing the inherently contextual nature of public values makes it impossible to say that things "must be getting better." The present era (and culture) is not necessarily more or less corrupt than past eras (or other cultures), because public morality acquires meaning in its own contextual frame of reference. This equally implies that universal definitions of corruption are of limited use, and that the same anti-corruption measures do not apply to all circumstances.

Another lesson for the present is offered by looking at the function of public debate. As the Repelaer scandal shows (and many scandals like it, see Hoenderboom, 2013; Kerkhoff, 2013b; Kroeze, 2013), public debate on corruption and integrity is crucial for any change in public values and, thereby, the potential to curb corruption and build integrity. This is an important insight when one considers the amount of energy put into designing legal codes and penalties after the fact, rather than discussing public values beforehand. The importance of public debate, as opposed to strictly legal action, is further underscored by the fact that most "corruption" is not truly a matter of legality. After all, what is legal is not necessarily morally acceptable, and vice versa. Furthermore, the function of debate shows that change in public values and morality is a long-term process. Present-day public values and public integrity are the result of centuries of debate and conflict. This offers an important lesson, for instance, when we consider whether it is realistic for donor organizations to demand near-instant improvement of societies with supposed high levels of corruption.

To conclude - and to look ahead - this article contends that a detailed historical narrative of public value dynamics in the Dutch context can and should be used to inform future comparative historical research on public value dynamics in a wider European context (cf. Engels, 2014; Kerkhoff, Kroeze, \& Wagenaar, 2013), and is an applicable methodology for other countries as well. This article is meant to underscore the relevance of the Dutch context as a mirror for wider European developments during the European Enlightenment (cf. Frijhoff, 2010; Leeb, 1973, p. 247; Palmer, 1974, p. 323; Van Berkel, Frijhoff, \& Te Velde, 2010), and offers material to inform the analysis of other, more well known, contexts. Comparison, most notably, with studies on Germany/Prussia (Bernsee, 2013; Engels, 2006; Wagner, 2005), France (Ebhardt, 2013; Engels, 2009; Simon, 2001), England (cf. Harling, 2003; Krischer, 2011; Rivers, 1991; Rubinstein, 1983; Wilson, 2007), Venice (Nützenadel, 2009), Russia (Schattenberg, 2009), and Switzerland (Lerner, 2011) can yield interesting results. Comparative questions could ask whether similar trends toward value monism occurred elsewhere, whether the influence of politicization and bureaucratization was similar or differed from place to place, and what were the decisive moments and trends in other historical contexts. As such, an historical research agenda for public values and integrity offers enormous possibilities for attaining a better understanding of the normative foundations of European and other states in the past and present.

\section{ACKNOWLEDGMENTS}

The author wishes to thank the anonymous reviewers for their comments on earlier versions of this article.

\section{REFERENCES}

Adams, J. (2005). The familial state: Ruling families and merchant capitalism in early modern Europe. Ithaca, NY: Cornell University Press. 
Baker, K. M. (1987). The French Revolution and the creation of modern political culture. Oxford, UK: Pergamon.

Bareuth, J. (1783). De oude onschatbare vrijheid, en eerste edele grondwet der burgeren en inwooneren te Dordrecht, ten proefsteen genoomen het patriotismus derzelver regeering daarop te toetsen [The old invaluable freedom, and first noble constitution, of the citizens of Dordrecht tested against its government's patriotism]. Royal Library, The Hague. Early Modern Pamphlets Online, Catalogue of Knuttel: Pamphlets held in the Dutch Royal Library (1486-1853), Pamphlet number 20310.

Bayly, C. A. (2004). The birth of the modern world, 1780-1914: Global connections and comparisons. Malden, MA: Blackwell.

Bedenkingen over het aanstellen van regenten, in een vry gemeenebest [Thoughts on the appointment of regents in a free commonwealth]. (1787). Royal Library, The Hague. Early Modern Pamphlets Online, Catalogue of Knuttel: Pamphlets held in the Dutch Royal Library (1486-1853), Pamphlet number 21515.

Bernsee, R. (2013). Corruption in German political discourse between 1780 and 1820: A categorisation. Journal of Modern European History, 11(1), 52-71.

Blockmans, W. P. (1988). Patronage, brokerage and corruption as symptoms of incipient state formation in the Burgundian-Habsburg Netherlands. In A. Mączak \& E. Müller-Luckner (Eds.), Klientelsysteme im Europa der Frühen Neuzeit [Clientele systems in Europe of the early modern period] (pp. 117-126). Munich, DE: R. Oldenbourg.

Bozeman, B. (2007). Public values and public interest: Counterbalancing economic individualism. Washington, DC: Georgetown University Press.

Brans, M., \& Rossbach, S. (1997). The autopoiesis of administrative systems: Niklas Luhmann on public administration and public policy. Public Administration, 75(3), 417-439. doi:10.1111/1467-9299.00068

Broersma, M. (2005). Constructing public opinion. Dutch newspapers on the eve of a revolution (1780-1795). In J. W. Koopmans (Ed.), News and politics in early modern Europe 1500-1800 (pp. 219-235). Leuven, BE: Peeters.

Buchan, B., \& Hill, L. (2014). An intellectual history of political corruption. Basingstoke, UK: Palgrave Macmillan.

De Zwart, F. (2010). Corruption and anti-corruption in prismatic societies. In G. De Graaf, P. Von Maravic, \& F. P. Wagenaar (Eds.), The good cause: Theoretical perspectives on corruption (pp. 36-46). Opladen, DE, \& Farmington Hills, MI: Barbara Budrich.

De herstelde vrijheid aan de welmenende en burgerlievende regenten der stad Dordrecht [The restored freedom of the regents of Dordrecht]. (1782). Royal Library, The Hague. Early Modern Pamphlets Online, Catalogue of Knuttel: Pamphlets held in the Dutch Royal Library (1486-1853), Pamphlet number 20310a.

Ebhardt, C. (2013). In search of a political office: Railway directors and electoral corruption in Britain and France, 1820-1870. Journal of Modern European History, 11(1), 72-87.

Engels, J. I. (2006). Politische Korruption in der Moderne, Debatten und Praktiken in Grossbritannien und Deutschland im 19. Jahrhundert [Political corruption in modern times, debates and practices in Great Britain and Germany in the nineteenth century]. Historische Zeitschrift, 282(2), 313-350.

Engels, J. I. (2009). Revolution and Panama. Korruptionsdebatten als Systemkritiek in Frankreich vom 18. Jahrhundert bis zur Dritten Republik [Revolution and Panama. Corruption debates as system critique in France from the eighteenth century to the Third Republic]. In J. I. Engels, A. Fahrmeir, \& A. Nützenadel (Eds.), Geld, Geschenke, Politik: Korruption im neuzeitlichen Europa [Money, gifts and politics: Corruption in early modern Europe] (pp. 143-174). Munich, DE: Oldenbourg.

Engels, J. I. (2014). Die Geschichte der Korruption. Von der Frühen Neuzeit bis ins 20. Jahrhundert [The history of corruption from early modern times to the twentieth century]. Frankfurt am Main, DE: S. Fischer Geschichte.

Frederickson, H. G. (1999). Ethics and the new managerialism. Public Administration \& Management, 4(2), $299-324$.

Friedrich, C. J. (1989). Corruption concepts in historical perspective. In A. J. Heidenheimer, M. Johnston, \& V. T. LeVine (Eds.), Political corruption: A handbook (pp. 15-24). New Brunswick, NJ, and Oxford, UK: Transaction Publishers.

Frijhoff, W. (2010). The relevance of Dutch history; or, Much in little? Reflections on the practice of history in the Netherlands. The Low Countries Historical Review, 125(2-3), 7-44. doi:10.18352/bmgn-lchr.7114

Gabriëls, A. J. C. M. (1989). De heren als dienaren en de dienaar als heer: het stadhouderlijk stelsel in de tweede helft van de 18de eeuw [The masters as servants and the servants as masters, the Stadtholderly system in the second half of the eighteenth century]. The Hague, NL: Stichting Hollandse Historische Reeks.

Groenveld, S., \& Wagenaar, F. P. (2011). De Republiek der Verenigde Nederlanden: het 'makelaarskarakter' van het Nederlandse openbaar bestuur tussen 1555 en 1795 [The Republic of the United Provinces: The 'brokerage character' of Dutch public administration between 1555 and 1795]. In F. P. Wagenaar, A. D. N. Kerkhoff, \& M. R. Rutgers 
(Eds.), Duizend jaar openbaar bestuur in Nederland: Van patrimoniaal bestuur naar waarborgstaat [A thousand years of Dutch public administration: From patrimonial administration to enabling state] (pp. 91-148). Bussum, NL: Coutinho.

Grüne, N., \& Tölle, T. (2013). Corruption in the Ancien Régime: Systems-theoretical considerations on normative plurality. Journal of Modern European History, 11(1), 31-51.

Harling, P. (2003). Parliament, the state, and "old corruption": Conceptualizing reform, c. 1790-1832. In A. Burns \& J. Innes (Eds.), Rethinking the age of reform: Britain 1780-1850 (pp. 98-113). Cambridge, UK: Cambridge University Press.

Heidenheimer, A. J., \& Johnston, M. (2001). Political corruption: Concepts and contexts (3rd ed.). New Brunswick, NJ: Transaction.

Hewitson, M. (2014). History and causality. Basingstoke, UK: Palgrave MacMillan.

Hiller, P. (2010). Understanding corruption: How systems theory can help. In G. De Graaf, P. Von Maravic, \& F. P. Wagenaar (Eds.), The good cause. Theoretical perspectives on corruption (pp. 64-82). Opladen, DE, \& Farmington Hills, MI: Barbara Budrich.

Hoenderboom, M. P. (2013). Scandal, politics and patronage: Corruption and public values in the Netherlands (1650-1747) (Unpublished doctoral dissertation). Vrije Universiteit Amsterdam, Amsterdam, NL.

Huiskamp, R. (1995). Tussen centrum en periferie. Giften en corruptie in de vroegmoderne politiek [Between center and periphery. Gifts and corruption in early modern politics]. Volkskundig bulletin, 21(1), 27-58.

Intressant vertoog over het bedanken voor zijne doorlugtige hoogheids recommendatien door de vroedschappen van verscheide aanzienlijke steden van Holland gedaan [Exposé on the end of his highness' recommendations]. (1782). Royal Library, The Hague. Early Modern Pamphlets Online, Catalogue of Knuttel: Pamphlets held in the Dutch Royal Library (1486-1853), Pamphlet number 20300.

Israel, J. I. (1998). The Dutch republic: Its rise, greatness, and fall, 1477-1806. Oxford, UK: Clarendon Press.

Johnston, M. (1996). The search for definitions: The vitality of politics and the issue of corruption. International Social Science Journal, 149(3), 321-336.

Johnston, M. (2005). Syndromes of corruption: Wealth, power and democracy. Cambridge, UK: Cambridge University Press.

Jørgensen, B. T. (2009). Value dynamics and infrastructure reform. International Journal of Public Policy, 4(5), 449-457. doi:10.1504/ijpp.2009.025082

Jørgensen, B. T., \& Bozeman, B. (2007). Public values: An inventory. Administration and Society, 39(3), 354-381. doi: $10.1177 / 0095399707300703$

Jørgensen, B. T., \& Rutgers, M. R. (2014). Tracing public values change: A historical study of civil service job advertisements. Contemporary Readings in Law and Social Justice, 6(2), 59-80.

Jørgensen, B. T., \& Vrangbæk, K. (2011). Value dynamics: Towards a framework for analyzing public value changes. International Journal of Public Administration, 34, 486-496. doi:10.1080/01900692.2011.583776

Jørgensen, B. T., Vrangbæk, K., \& Sørensen, D.-L. (2009). The historical development of values in Danish administrative reform. Paper presented at the EGPA conference on "The public service: Service delivery in the information age," St. Julians, Malta. https://www.law.kuleuven.be/integriteit/egpa/previous-egpa-conferences/malta-2009/jorgenssen.pdf

Kerkhoff, A. D. N. (2011). Organizational reform and changing ethics in public administration: A case study on 18th century Dutch tax collecting. Journal of Public Administration Research and Theory, 21(1), 117-135. doi:10.1093/ jopart/mup042

Kerkhoff, A. D. N. (2013a). Changing perceptions of corruption in the Netherlands: From early modern pluralism to modern coherence. Journal of Modern European History, 11(1), 88-108.

Kerkhoff, A. D. N. (2013b). Hidden morals, explicit scandals. Public values and political corruption in the Netherlands (1748-1813) (Unpublished doctoral dissertation). Leiden University, Leiden, NL.

Kerkhoff, A. D. N. (2014). Early modern developments in Dutch public administration: Patriot and Batavian authors on public morality (1770s-1813). Administrative Theory \& Praxis, 36(1), 73-94. doi:10.2753/atp1084-1806360105

Kerkhoff, A. D. N., \& Wagenaar, F. P. (2015). History, public ethics and the anti-corruption industry. In A. Lawton, Z. Van der Wal, \& L. W. Huberts (Eds.), Ethics in public policy and management: A global research companion (pp. 69-86). London, UK: Routledge.

Kerkhoff, A. D. N., Kroeze, D. B. R., \& Wagenaar, F. P. (2013). Corruption and the rise of modern politics in Europe in the eighteenth and nineteenth centuries: A comparison between France, the Netherlands, Germany and England. Introduction. Journal of Modern European History, 11(1), 19-30. 
Kerkhoff, A. D. N., Hoenderboom, M. P., Kroeze, D. B. R., \& Wagenaar, F. P. (2010). Dutch political corruption in historical perspective: From 18th century value pluralism to a 19th century dominant liberal value system and beyond. In N. Grüne \& S. Slanicka (Eds.), Korruption. Historische Annäherungen an eine Grundfigur politischer Kommunikation [Corruption. Historical approaches to a basic form of political communication] (pp. 443-468). Göttingen, DE: Vandenhoeck \& Ruprecht.

Kolthoff, E. W. (2007). Ethics and new public management: Empirical research into the effects of businesslike government on ethics and integrity. Annandale, NSW, AU: Federation Press.

Koselleck, R. (1972). Einleitung [Introduction]. In O. Brunner, W. Conze, \& R. Koselleck (Eds.), Geschichtliche Grundbegriffe. Historisches Lexikon zur politisch-sozialen Sprache in Deutschland [Basic historical concepts: Historical dictionary of political and social language in Germany] (Vol. 1, pp. xiii-xxvii). Stuttgart, DE: Klett-Cotta.

Krischer, A. (2011). Korruption vor gericht. Die Fälle Francis Bacon (1621), Warren Hastings (1788-1795) und der Strukturwandel bei der Bewertung politischer Delinquenz in England [Corruption in court. The cases of Francis Bacon (1621), Warren Hastings (1788-1795) and structural change in the assessment of political delinquency in England]. In N. Grüne \& S. Slanička (Eds.), Korruption. Historische Annäherungen an eine Grundfigur politischer Kommunikation [Corruption. Historical approaches to a basic form of political communication] (pp. 307-326). Göttingen, DE: Vandenhoeck \& Ruprecht.

Kroeze, R. (2013). Een kwestie van politieke moraliteit: politieke corruptieschandalen en goed bestuur in Nederland, 1848-1940 [A question of political morality: Political corruption scandals and good governance in the Netherlands, 1848-1940]. Hilversum, NL: Verloren.

Leeb, I. L. (1973). The ideological origins of the Batavian revolution: History and politics in the Dutch republic 1747-1800. The Hague, NL: Nijhoff.

Lerner, M. (2011). The search for the origins of modern democratic republican political thought in early modern Switzerland. Modern Intellectual History, 8(3), 647-658. doi:10.1017/s1479244311000382

Luhmann, N. (1970). Soziologische Aufklaerung [Sociological clarification]. Opladen, DE: Westdeutscher Verlag.

Luhmann, N. (1980). Gesellschaftsstruktur und Semantik: Studien zur Wissenssoziologie der modernen Gesellschaft [Social structure and semantics: Studies on sociology of knowledge of modern society] (Vol. 1). Frankfurt am Main, DE: Suhrkamp.

Maesschalck, J. (2004). The impact of new public management reforms on public servants' ethics: Towards a theory. Public Administration, 82(2), 465-489. doi:10.1111/j.0033-3298.2004.00403.x

Mahoney, J., \& Rüschemeyer, D. (Eds.). (2003). Comparative historical analysis in the social sciences. Cambridge, UK: Cambridge University Press.

Missive van den heer L. V. J. aan den heer P. G. Z. inhoudende de waare redenen, en motiven, die zeven regenten der stad Dordregt hebben weerhouden, om tot de bewuste conventie toe te treeden [Letter of Sir L. V. J. to Sir P. G. Z. on the reasons why Dordrecht's regents did not enter the convention]. (1782). Royal Library, The Hague. Early Modern Pamphlets Online, Catalogue of Knuttel: Pamphlets held in the Dutch Royal Library (1486-1853), Pamphlet number 20296.

Missive van een Haagsch Patriot aan een welmeenend regent, te Gouda over het voorbeeldig gedrag der steden Dordrecht, Leyden, Schiedam enz [Letter from a Patriot from The Hague]. (1782). Royal Library, The Hague. Early Modern Pamphlets Online, Catalogue of Knuttel: Pamphlets held in the Dutch Royal Library (1486-1853), Pamphlet number 20295.

Molhuysen, P. C., Blok, P. J., Knappert, L., \& Kossmann, F. K. H. (Eds.). (2008). Nieuw Nederlandsch biografisch woordenboek [New Dutch Biographical Dictionary]. Leiden, NL: DBNL.

Nützenadel, A. (2009). "Serenissima corrupta"-Geld, Politik und Klientelismus in der späten venetianischen Adelsrepublik ["Serenissima corrupta"-Money, politics and patronage in the late Venetian nobility Republic]. In J. I. Engels, A. Fahrmeir, \& A. Nützenadel (Eds.), Geld-Geschenke-Politik. Korruption im neuzeitlichen Europa [Money, gifts and politics: Corruption in early modern Europe] (pp. 121-142). Munich, DE: Oldenbourg.

Oyserman, D. (2001). Values: Psychological perspectives. In N. J. Smelser \& P. B. Baltes (Eds.), International encyclopedia of the social \& behavioral sciences. (pp. 16148-16153). Amsterdam, NL: Elsevier.

Palmen, E. (1998). De politieke elite [The political elite]. In W. Frijhoff, H. Nusteling, \& M. Spies (Eds.), Geschiedenis van Dordrecht van 1572 tot 1813 [A history of Dordrecht from 1572 to 1813] (pp. 211-220). Dordrecht, DE: Stadsarchief Dordrecht \& Uitgeverij Verloren. 
Palmer, R. R. (1954). Much in little: The Dutch revolution of 1795. Journal of Modern History, 26(I), 15-35. doi:10.1086/237660

Palmer, R. R. (1974). The age of the democratic revolution: A political history of Europe and America, 1760-1800 (3rd ed.). Princeton, NJ: Princeton University Press.

Pierson, P. (2003). Big, slow-moving, and ... invisible. Macrosocial processes in the study of comparative politics. In J. Mahoney \& D. Reuschemeyer (Eds.), Comparative historical analysis in the social sciences (pp. 177-207). Cambridge, UK: Cambridge University Press.

Pierson, P., \& Skocpol, T. (2002). Historical institutionalism in contemporary political science. In I. Katznelson \& H. V. Milner (Eds.), Political science: The state of the discipline (pp. 693-721). New York \& London: W.W. Norton \& Co.

Pollmann, J. S., \& Spicer, A. (Eds.). (2007). Public opinion and changing identities in the early modern Netherlands. Leiden, NL: Brill.

Price, J. L. (1994). Holland and the Dutch republic in the seventeenth century: The politics of particularism. Oxford, UK: Clarendon Press.

Raadschelders, J. C. N. (1994). Administrative history: Contents, meaning and usefulness. International Review of Administrative Sciences, 60(1), 117-129.

Raadschelders, J. C. N. (2000). Handbook of administrative history (1st paperback ed.). New Brunswick, NJ: Transaction Publishers.

Raadschelders, J. C. N., \& Rutgers, M. R. (1996). The evolution of civil service systems. In A. J. G. M. Bekke, J. L. Perry, \& T. A. J. Toonen (Eds.), Civil service systems in comparative perspective (pp. 67-99). Bloomington, IN: Indiana University Press.

Repelaer, H. (1772), Extract uit de resolutiën van de Staten Generaal betreffende de benoeming van Paulus van der Heim tot 2 e secretaris van het college ter Admiraliteit op de Maze [Extract from resolutions of the States General on the appointment of Paulus van der Heim to 2nd secretary of the Admiralty of the Maze]. Family Archive Repelaer (1496-1940). National Archives, The Hague. Access number 1.10.70, inventory number 20, appendix c.

Repelaer, H. (1779), Request van Hugo Repelaer, ontvanger van de convooien en licenten te Dordrecht, aan de Staten Generaal om zijn zoon Ocker als assistent bij zijn ambt te mogen aannemen [Request by Hugo Repelaer to the States General to have his son Ocker appointed as his assistant receiver of convoys and licences]. Family Archive Repelaer (1496-1940). National Archives, The Hague. Access number 1.10.70, inventory number 20.

Richter, M. (1995). The history of political and social concepts: A critical introduction. New York: Oxford University Press.

Riggs, F. W. (1964). Administration in developing countries: The theory of prismatic society. Boston, MA: Houghton Mifflin.

Rivers, I. (1991). Reason, grace, and sentiment: A study of the language of religion and ethics in England, 1660-1780. Cambridge, UK: Cambridge University Press.

Rubinstein, W. D. (1983). The end of "old corruption" in Britain, 1780-1860. Past and Present: A Journal of Historical Studies, 101, 55-86.

Rutgers, M. R. (2008). Sorting out public values? On the contingency of value classification in public administration. Administrative Theory \& Praxis, 30(1), 92-113.

Schama, S. (1977). Patriots and liberators: Revolution in the Netherlands, 1780-1813. New York: Knopf.

Schattenberg, S. (2009). Die Ehre der Beambten oder: Warum die Staatsdiener nicht korrupt waren. Patronage in der russischen Provinzverwalting im 19. Jahrhundert [The honor of public servants or: Why public servants were not corrupt. Patronage in the Russian provincial administration of the nineteenth century]. In J. I. Engels, A. Fahrmeir, \& A. Nützenadel (Eds.), Geld, Geschenke, Politik: Korruption im neuzeitlichen Europa [Money, gifts and politics: Corruption in early modern Europe] (pp. 203-230). Munich, DE: Oldenbourg.

Simon, J. (2001). Beyond contractual morality: Ethics, law, and literature in eighteenth-century France. Rochester, NY: University of Rochester Press.

Stapelbroek, K. (2010). Dutch decline as a European phenomenon. History of European Ideas, 36(2), 139-152.

Swildens, J. H., Van der Capellen, J., \& Van der Capellen van de Marsch, R. J. (1785). Grondwettige herstelling van Nederlands staatswezen [The constitutional restoration of the Dutch state]. Amsterdam, NL: Johannes Allart.

Thelen, K. (2002). The explanatory power of historical institutionalism. In R. Mayntz (Ed.), Akteure, Mechanismen, Modelle [Actors, mechanisms, models] (pp. 91-107). Frankfurt am Main, DE: Campus Verlag. 
Tilly, C. (2008). Why and how history matters. In R. E. Goodin \& C. Tilly (Eds.), The Oxford handbook of contextual political analysis (pp. 417-437). Oxford, UK: Oxford University Press.

Tweetal lofdichten op de pattriottische resolutie van Dordrecht, genoomen den 6 Augustus, aan den stadhouder medegedeeld 8 Augustus 1782 [Two poems on the Patriot resolution of Dordrecht]. (1782). Royal Library, The Hague. Early Modern Pamphlets Online, Catalogue of Knuttel: Pamphlets held in the Dutch Royal Library (1486-1853), Pamphlet number 20297.

Van Berkel, K., \& Goei, L. de (Eds.). (2010). The international relevance of Dutch history. Special Issue of the Low Countries Historical Review, 125(23). The Hague, The Netherlands: Royal Netherlands Historical Society.

Van der Wal, Z., Nabatchi, T., \& De Graaf, G. (2013). From galaxies to universe: A cross-disciplinary review and analysis of public values publications from 1969 to 2012. American Review of Public Administration, 45(1), 13-28. doi:10.1177/0275074013488822

Van Gestel, N., Koppenjan, J., Van de Schrijver, I., Van de Ven, A., \& Veeneman, W. (2008). Managing public values in public-private networks: A comparative study of innovative public infrastructure projects. Public Money and Management, 28(3), 139-145. doi:10.1111/j.1467-9302.2008.00635.x

Van Putten, G. (1782). De Gulde Legende van den Heere Hugo Repelaer [The golden legend of Sir Hugo Repelaer]. Royal Library, The Hague. Early Modern Pamphlets Online, Catalogue of Knuttel: Pamphlets held in the Dutch Royal Library (1486-1853), Pamphlet number 20278.

Van Sas, N. C. F. (2005). De metamorfose van Nederland: Van oude orde naar moderniteit, 1750-1900 [The metamorphosis of the Netherlands: from old order to modernity, 1750-1900]. Amsterdam, NL: Amsterdam University Press.

Von Thiessen, H. (2009). Korruption und Normenkonkurrenz. Zur Funktion und Wirkung von Korruptionsvorwürfen gegen die Günstling Minister Lerma und Buckingham in Spanien und England im frühen 17. Jahrhundert [Corruption and competition of norms. About the function and effect of corruption charges against the favorite minister Lerma and Buckingham in Spain and England in the early 17th century]. In J. I. Engels, A. Fahrmeir, \& A. Nützenadel (Eds.), Geld-Geschenke-Politik. Korruption im neuzeitlichen Europa [Money, gifts and politics: Corruption in early modern Europe] (pp. 91-120). Munich, DE: Oldenbourg.

Von Thiessen, H. (2010). Korrupte Gesandte? Konkurrierende Normen in der Diplomatie der Frühen Neuzeit [Corrupt Messengers? Competing standards in the diplomacy of the early modern period]. In N. Grüne, \& S. Slanička (Eds.), Korruption. Historische Annäherungen an eine Grundfigur politischer Kommunikation [Corruption. Historical approaches to a basic form of political communication] (pp. 205-220). Göttingen, DE: Vandenhoeck \& Ruprecht.

Wagenaar, F. P. (2011). Extortion and Abuse of Power in the Dutch Republic: The Case of Bailiff Lodewijk van Alteren. International Journal of Public Administration, 11, 731-740.

Wagner, P. (2005). Bauern, Junker und Beamtelokale Herrschaft und Partizipation im Ostelbien des 19. Jahrhunderts [Farmers, nobility and local government officials and participation in East Elbia in the nineteenth century]. Göttingen, DE: Wallstein.

Waquet, J. C., \& McCall, L. (1991). Corruption, ethics and power in Florence, 1600-1770. Cambridge, UK: Polity Press.

Welskopp, T. (2010). "Honest Graft"-"Ehrbare Bestechung”. In N. Grüne \& S. Slanička (Eds.), Korruption. Historische Annäherungen an eine Grundfigur politischer Kommunikation [Corruption. Historical approaches to a basic form of political communication] (pp. 221-245). Göttingen, DE: Vandenhoeck \& Ruprecht.

Wilson, B. (2007). The making of Victorian values: Decency and dissent in Britain, 1789-1837. New York: Penguin Press.

Zwitser, H. L. (Ed.). (1987). Joan Derk van der Capellen. Aan het volk van Nederland. Het patriottisch program uit 1781 [Joan Derk van der Capellen. To the People of The Netherlands. The Patriot program of 1781]. Amsterdam, NL. 